\title{
Microbial Degradation of Petroleum Hydrocarbons and Factors Influencing the Degradation Process
}

\author{
Supriya Jadhav, Sameer Sharma, Sibi G* \\ Department of Biotechnology, Indian Academy Degree College-Autonomous, Bengaluru, India \\ Email address: \\ gsibii@gmail.com (Sibi G) \\ ${ }^{*}$ Corresponding author

\section{To cite this article:} \\ Supriya Jadhav, Sameer Sharma, Sibi G. Microbial Degradation of Petroleum Hydrocarbons and Factors Influencing the Degradation Process. \\ Bioprocess Engineering. Vol. 3, No. 2, 2019, pp. 6-11. doi: 10.11648/j.be.20190302.12
}

Received: December 10, 2019; Accepted: December 20, 2019; Published: December 26, 2019

\begin{abstract}
Hydrocarbon compounds have been noted to reside the family of neurotoxic and xenobiotic organic pollutants and nowadays petroleum hydrocarbon compounds continually being a major natural worry because of the development of petroleum oil extraction and related products which have major ecological issue. Oil seepage normally happen by mishaps pumping, transportation and refining and petroleum products consist of carcinogenic and mutagenic compounds which could have several consequences on biotic and abiotic factors of the ecosystem. Mainly two methods such as mechanical and chemical methods are normally used to remove hydrocarbons from contaminated places have effectiveness and can be expensive. Bioremediation is the best and advance technology for the treatment of these contaminated places because it is not much expensive and will lead to whole mineralization. Microbial degradation is the major and ultimate natural mechanism by which one can clean up the petroleum hydrocarbon pollutants from the environment. Many indigenous micro-organisms in water and soil are able to degrading hydrocarbon contaminants. A number of limiting factors have been recognized to affect the biodegradation of petroleum hydrocarbons. This review summarizes the microbial degradation of petroleum hydrocarbons aerobically and anaerobically and various factors that influencing the process. It may be concluded that microbial degradation can be considered as a key component in the cleanup strategy for petroleum hydrocarbon remediation.
\end{abstract}

Keywords: Hydrocarbon Contaminants, Bioremediation, Aerobic and Anaerobic Degradation

\section{Introduction}

In industries and daily routine life, the petroleum based products are the important source of energy and mainly extraction, transportation, refinement, leakage becomes a harmful contamination issue across the world [1-6]. Petroleum hydrocarbons are combinations of numerous carbon bonds that made complex structures when they attached to each other such as aliphatic alkanes, alkenes and polycyclic aromatic hydrocarbons. The amount of indigenous crude oil seepage was measured to be 550000 metric tons per annum with the approach of uncertainty of 200000 metric tons per year [7]. Due to human activities or any other process that leads to release of hydrocarbons into the environment are the major agents of water and soil pollutions [8]. In terms of soil contamination with hydrocarbons leads to extensive damage to animals and plant materials that may cause mutations and also maybe leads to death [9]. Many scientific opinions have discussed about various process that influences the rate of oil biodegradation [10-15]. Normally, two main process to oil spills in bioremediation 1) bio-augmentation, in which oil degrading bacteria are indulged in existing microbial population and 2) bio-stimulation, in which the growth rate of oil degraders is enhanced by the addition of supplements [16-19]. Bioremediation process resolves most of physical and chemical problems using the metabolic capability exploitation of diverse remarkable microorganisms. The physico-chemical techniques evolving in biodegradation process that degrading xenobiotic compounds because of high efficiency and effortlessness process $[20,21]$. In this article, we focused on aerobic and anaerobic microbial degradation of petroleum hydrocarbons with factors influencing the process. 


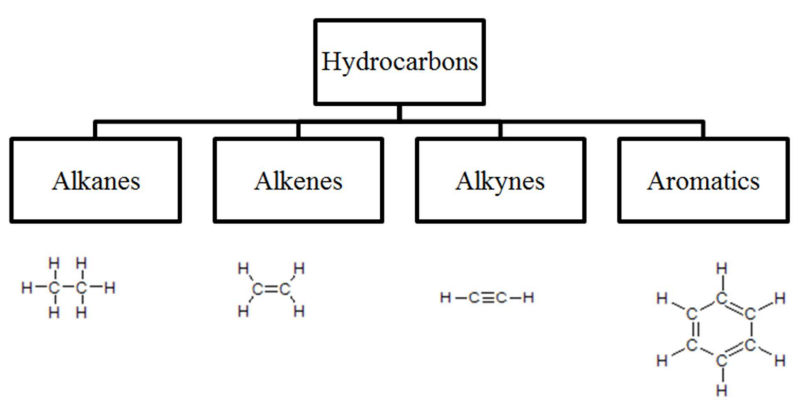

Figure 1. Types of hydrocarbons in essence alkanes, alkenes, alkynes and aromatics.

\section{Microbial Degradation of Contaminated Petroleum Hydrocarbons}

The bioremediation strategies are the convenient way for microbial choice which had the capability to degrade contaminants without losing the microbial growth and competing other family of microorganisms such as Alkane $\left(\mathrm{C}_{5}-\mathrm{C}_{12}\right.$ n-alkanes), nah (naphthalene) and xylene (toluene) were the most common microbial destructive pathways related to petroleum hydrocarbon deterioration [22, 23]. Petroleum hydrocarbon can be divided into 4 classes in essence saturates, aromatics, asphaltenes and the resins [24]. Microbial deterioration is the main indigenous mechanism in which one can clear the contaminated petroleum hydrocarbon from the environments [25-27].

The apperception of biodegraded sediments of petroleum based aromatic hydrocarbon was noted by Jones et al [28]. Bacterial or microbial communities are the most known and impressive in petroleum oil deterioration and considered as major oil seepage degraders in environment and its particular genes is correlated with hydrocarbon disintegration and now an important part in the deterioration process of petroleum sediments [29-31]. Biodegradation of petroleum based hydrocarbon in the environment commonly by bacteria, fungi, and yeast. Bacteria are the uttermost active agents in petroleum deterioration and they work as initial degraders of oil seepage in environment $[31,32]$ and various bacteria are better to feed or degrade the hydrocarbons [30]. Floodgate [33] noted 26 genera of hydrocarbon feeding bacteria and bacterial genera namely Gordonia, Brevibacterium, Dietzia, and Mycobacterium isolated from contaminated soil for hydrocarbon degradation [34].

Polyaromatic hydrocarbon degradation by Sphingomonas was observed by Daugulis and McCracken [35] and Fungal genera commonly, Amorphoteca, Neosartorya, and talaromyces as well as yeast genera namely, Yarrowia candida were observed from contaminated petroleum soil [36]. Although protozoa and algae are the major unit of the microbial family $n$ both terrestrial and aquatic ecosystems and observed their involvement in hydrocarbon deterioration.

Fungi also have petroleum hydrocarbon deterioration efficiency by the chemical process and upgraded availability of pollutants and possess many non-specific enzymes that arises the degradation mechanism [37]. Laccases, transferase, cytochrome P450 monooxygenase and various enzymes are used as basic process of microflora activities in contaminated soil [38]. Mycoflora role in biodegradation mechanism of different petroleum outcomes has been widely tested such as Aspergillus, Cephalosporium, Gliocladium, paecilomyces, Mucor, and Torulopsis [39, 40]. First filamentous fungi Cladosporium resinae with the capability to absorb petroleum products was found in contaminant jet fuels and cause serious problems in aircraft industries [41-45]. Investigated around 50 fungal strains for their abilities to utilize crude oils and the isolated oil degrading fungi from contaminated soil were Verticillium spp., Scolecobasidium obovatum and Tolypocladium inflatum.

Yeast also has a major concurrence in microbial deterioration of petroleum hydrocarbons like Candida lipolytica and geotrichum sp., which are observed from petroleum contaminated water and might degrade various petroleum factors [45]. Pleurotus tuberregium raises the soil content to reducing heavy metal concentration after half a year of incubation and a report showed the capacity of Lentinus squarrosulus, white rot fungus to increase the nutrient concentrations in the same oil engine contaminated soil. Algae are treated as microbial conference in aquatic and terrestrial environments and there are limited proofs about algae degradation capability of petroleum contaminants in indigenous environments $[46,47]$.

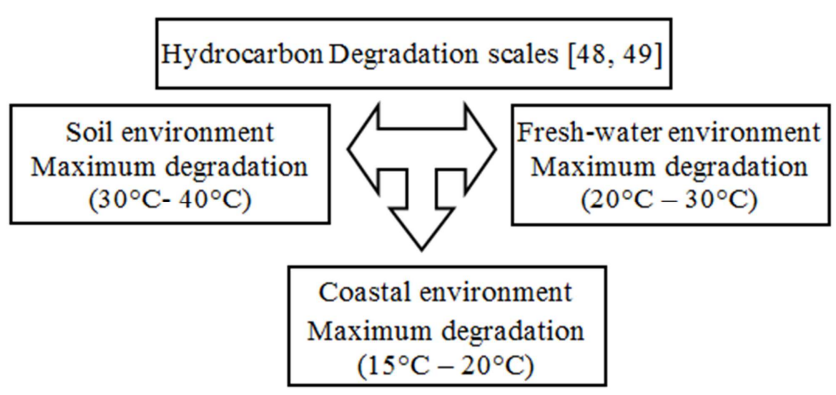

Figure 2. Hydrocarbon degradation scales in soil, fresh-water and coastal environments.

\section{Aerobic and Anaerobic Routes in Petroleum Hydrocarbon Biodegradation}

Petroleum hydrocarbons are biodegraded both aerobically and anaerobically process by yeast, fungi, and bacteria with different degradation amounts $[21,50]$. Presence or absence of oxygen is considered for basic deterioration of compound mixtures of petroleum hydrocarbon contaminants such as presence of oil in soil.

Aerobic degradation is the largest responsive and complete mechanism for the removing of petroleum hydrocarbon contaminants from the environments mainly aromatic types and with the help of enzymes and metabolic pathways in petroleum hydrocarbon deterioration has been considered, for example alkane monooxygenase, and cytochrome P450 
members are correlated with petroleum removal pathways [51, 52]. Under aerobic process, oxygenase initiates to cover benzene ring and start continuous ring cleavages [53]. One more study revealed that biodegradation of petroleum oil in gasoline-contaminated soil was fastest when oxygen consumption was $8 \%$ in oxygen concentrations.

Anaerobic degradation of contaminated hydrocarbons by microorganism in the absence of oxygen is significant pathway for microbial degradation of petroleum hydrocarbons that doesn't utilize the oxygenases aerobically [10, 54, 55]. Under anaerobic condition, microbes appeared to utilize various electron acceptors such as sulphate and iron that multiply the molecular oxygen in perspective of oxygen and oxidize various hydrocarbons petroleum groundwater [56-58]. Anaerobic metabolic pathways like deep soil where oxygen diffusion is restricted. In presence of oxygen, aliphatic and aromatic hydrocarbon deterioration is faster and may leads to hydrocarbon compound complex [59-61].

Table 1. Enzymes convoluted in bio-degradation of petroleum hydrocarbons.

\begin{tabular}{lll}
\hline Enzymes & Activators & Micro-organisms \\
\hline $\begin{array}{lll}\text { Solvable Methane Monooxygenases } \\
\text { Crude Methane Monooxygenases }\end{array}$ & Alkanes alkenes and Cyclo-alkanes $\left(\mathrm{C}_{1}-\mathrm{C}_{8}\right)$ & $\begin{array}{l}\text { Methylococcus, Methylosinus, Methylocystis, } \\
\text { Methylomonas }\end{array}$ \\
$\begin{array}{l}\text { Alkane correlated with Alkane } \\
\text { Hydroxylases }\end{array}$ & Alkanes, fatty acids, alkyl benzenes, cycloalkanes & Psethylobacter Methylococcus, Methylocystis \\
Eukaryotic P450s & $\left(\mathrm{C}_{5}-\mathrm{C}_{16}\right)$ & [62] \\
Microbial P450s oxygenase enzyme & $\left(\mathrm{C}_{10}-\mathrm{C}_{16}\right)$ alkanes, fatty acids & lipolytica maltosa Candida tropicalis Yarrowia \\
Di-oxygenases & $\left(\mathrm{C}_{5}-\mathrm{C}_{16}\right)$ alkanes, and cycloalkanes & [64] \\
& $\left(\mathrm{C}_{10}-\mathrm{C}_{30}\right)$ alkanes & Acinetobacter, Caulobacter, Mycobacterium \\
\hline
\end{tabular}

\section{Factors Influencing the Microbial Petroleum Hydrocarbons Deterioration}

\subsection{Chemical and Physical State of Oil}

Microbial deterioration of petroleum hydrocarbons varied on their different chemical compositions. Shorter chain compounds are more toxic than longer chain like n-alkanes of intermediate length $\left(\mathrm{C}_{10}-\mathrm{C}_{25}\right)$ [66] and longer chain alkanes are hydrophobic solid in nature and very hard to degrade due to poor water solubility. Branched chain alkanes and also cycloalkanes degraded more slowly in process than common alkanes [65]. Dispersion of petroleum hydrocarbons in liquid column increases the surface area for microbial attack [66-67]. High concentration of hydrocarbons may be correlated with heavy formation of thick rafts which can be lead to the inhibition of microbial biodegradation by less oxygen [68].

\subsection{Temperature State}

In case of low temperature, the rates of volatilisation leads to low molecular mass of hydrocarbon which may be harmful to bacteria due to delay of biodegradation of oil. The optimal temperature ranges for petroleum hydrocarbon degrading microorganism are psychrophiles (below $20^{\circ} \mathrm{C}$ ), mesophiles $\left(15^{\circ} \mathrm{C}-45^{\circ} \mathrm{C}\right.$ ), and thermophiles (above $50^{\circ} \mathrm{C}$ ). Oil degrading microbes are active in the range of $20^{\circ} \mathrm{C}$ to $35^{\circ} \mathrm{C}$ temperature and commonly deterioration rates are slower in cold atmosphere than warm environments [48]. That is why the best option for biodegradation of petroleum hydrocarbons is mesophilic and thermophilic temperature ranges [48, 49].

\subsection{Water Enterprise}

All biological mechanism needs humidity for better transport of food and waste components in and out of the microbial cells. The water activity or water enterprise of soils may range from 0.1 to 0.99 in contrary to marine atmosphere in which water potential is suitable at near 0.98 values [54]. Biodegradation of hydrocarbon $n$ terrestrial ecosystem can be done by limited water for microbial viability and the optimal ratio of humidity will depend on whether and soil type and leads to ratio from $30 \%$ to $90 \%$ capacity [69].

\section{4. pH and Oxygen Effect}

$\mathrm{pH}$ effect on contaminated petroleum hydrocarbon can be good for terrestrial ecosystems as soil $\mathrm{pH}$ is extinct from 2.5 to 11 and mostly microbial families recommended neutral $\mathrm{pH}$ $[70,71]$. Involvement of oxidation of the substrates by enzymes such as oxygenase for molecular oxygen leads to destruction of aliphatic and aromatic hydrocarbons by microbes like fungi [72]. The presence of oxygen absorbs the different types of soil and soil textures which can lead to oxygen depletion [73]. In the absence of oxygen, the petroleum hydrocarbon by microbes has been shown in some studies [74].

\subsection{Salinity and Pressure}

Microbes are commonly well adapted to wide range of salinities in world's ocean [70] and there is no important proof to suggest that microbes are affected by another saline climate such as saltwater. Salinity values changes periodically in levels compare to ocean that is why if microbes came to climate through bio-augmentation process, it must be known if they are suitable with the saline levels present in atmosphere $[74,75]$. Biodegradation of contaminated hydrocarbons is most obviously restrained to deep sea atmosphere. The ambient temperature was noted less than the climate pressure therefore, oil present in deep ocean ecosystem will be deteriorated at a very slow rate by hydrocarbon degrading microbes. 


\section{Role of Phytoremediation in Contaminated Hydrocarbons}

In case of phytoremediation, the various strategies like phytovolatilization, rhizoremediation, and phytotransformation can be used for the remediation of a broad variety of pollutants. And phytoremediation is a promising technology that uses plants to stable a wide variety of environmental contaminants. This type of strategies can be expensive for broad sites with shallow residual levels of pollutants by organic nutrient where pollutant doesn't require where vegetation is utilized as a final closure of places [76].

Benefits of using phytoremediation indulge aesthetic changes, long term process, and cost effectiveness, furthermore the use of this type of strategies as an in-situ treatment step minimizes land disturbance and deletes transportation and associated with offsite treatment of waste materials. Recent studies revealed that phytoremediation for the cure of petroleum hydrocarbon pollutants over the past 10 years have done much research that may be used to develop better technologies and further improvement and innovation. Microbial deterioration in the roots could be the most proper mechanism for reducing or eliminate of diesel range organics in vegetated contaminant soils [77] and it occurs because of pollutants like PAHs are highly hydrophobic $n$ nature.

\section{Conclusion}

The process of the microbial degradation of petroleum hydrocarbons and other related contaminants product in the climate is a major issue and several factors like high concentration of the hydrocarbons are present. And the increasing viability of hydrocarbon degrading microbes in the environment could influence the mechanism of biodegradation. Bacteria and fungi are the prevalent microbial families that care the process of petroleum hydrocarbon biodegradation. Recently, the advance technologies like metagenomics analyses and other OMIC techniques which are friendly to ecosystem and have been introduced to analyse the genomic makeup of atmospherically microbes towards appraising their abilities and biodegradation of petroleum hydrocarbons.

\section{References}

[1] Al-Baldawi, I. A., Abdullah, S. R. S., Suja, F., Anuar, N. and Mushrifah, I. (2013). Effect of aeration on hydro-carbon phytoremediation capability in pilot sub-surface flow constructed wet land operation. Ecological Engineering. 61: 496-500.

[2] Masood, N., Zakaria, M. P., Ali, M. M., Magam, S. M., Alkhadher, S., Keshavarzifard, M., Vaezzadeh, V. and Hussein, M. A. Distribution of petroleum hydrocarbons in surface sediments from selected locations in Kuala Selangor River, Malaysia. In: From sources to solution. Springer 2014. ISBN: 978-981-4560-69-6.

[3] Deng, M. C., Li, J., Liang, F. R., Yi, M., Xu, X. M., Yuan, J. P., Peng, J., Wu, C. F. and Wang JH. (2014). Isolation and characterization of a novel hydrocarbon-degrading bacterium Achromobacter sp. HZ01 from the crude oil-contaminated seawater at the Daya Bay, southern China. Marine Pollution Bulletin. 83: 79-86.

[4] Bordoloi, S. and Basumatary, B. (2015). Phytoremediation of Hydrocarbon-contaminated soil using sedge species. In: Ansari A, Gill S, Gill R, Lanza G, Newman L (Eds) Phytoremediation. Springer, Cham.

[5] Hou, J., Liu, W., Wanga, B., Wang, Q., Luo, Y. and Franks, A. E. (2015). PGPR enhanced phytoremediation of petroleum contaminated soil and rhizosphere microbial community response. Chemosphere. 138: 592-598.

[6] Priya, A., Mandal, A. K., Ball, A. S., Manefield, M., Lal, B. and Sarma, P. M. (2015). Mass culture strategy for bacterial yeast co-culture for degradation of petroleum hydrocarbons in marine environment. Marine Pollution Bulletin100: 191-199.

[7] Kvenvolden, K. A. and Cooper, C. K. (2003). Natural seepage of crude oil into the marine environment. Geo-Marine Letters. 23: $140-146$.

[8] Holliger, C., Gaspard, S., Glod, G., Heijman, C., Schumacher, W., Schwarzenbach, R. P. and Vazques, F. (1997). Contaminated environments in the subsurface and bioremediation: organic contaminants. FEMS Microbiology Reviews. 20: 517-523.

[9] Alvarez, P. J. J. and Vogel, T. M. (1991). Substrate interactions of benzene, toluene, and para-xylene during microbial degradation by pure cultures and mixed culture aquifer slurries. Applied and Environmental Microbiology. 57: 2981-2985.

[10] Leahy, J. G. and Colwell, R. R. (1990). Microbial degradation of hydrocarbons in the environment. Microbiological Reviews. 54: 305-315.

[11] Zobell, C. E. (1946). Action of microorganisms on hydrocarbons. Bacteriological Reviews. 10: 1-49.

[12] Atlas, R. M. (1981). Microbial degradation of petroleum hydro-carbons: an environmental perspective. Microbiological Reviews. 45: 180-209.

[13] Atlas RM, Ed., Petroleum Microbiology, Macmillan, New York, NY, USA, 1984.

[14] Atlas, R. M. and Bartha, R. (1992). Hydrocarbon biodegradation and oil spill bioremediation. Advances in Microbial Ecology. 12: 287-338.

[15] Foght, J. M. Westlake, D. W. S. (1987). Biodegradation of hydrocarbons in freshwater. In: Oil in Freshwater: Chemistry, Biology, Counter measure Technology. Vandermeulen, J. H. and Hrudey, S. R. Pergamon Press, New York. 217-230.

[16] Prince, R. C. (1993). Petroleum spill bioremediation in marine environments. Critical Reviews in Microbiology. 19: 217-242.

[17] Swannell, R. P. J., Lee, K. and Mcdonagh, M. (1996). Field evaluations of marine oil spill bioremediation. Microbiological Reviews. 1996. 60: 342-365.

[18] Venosa, A. D., Suidan, M. T., Wrennm, B. A., Strohmeier, K. L., Haines, J. R., Eberhart, B. L., King, D. and Holder, E. (1996). Bioremediation of an experimental oil spill on the shoreline of Delaware Bay. Environmental Science and Technology. 30: 1764-1775. 
[19] Venosa, A. D., King, D. W. and Sorial, G. A. (2002). The baffled flask test for dispersant effectiveness: a round Robin evaluation of reproducibility and repeatability. Spill Science and Technology Bulletin. 7: 299-308.

[20] Khan, A. H. A., Tanveer, S., Anees, M., Muhammad, Y. S., Iqbal, M. and Yousaf, S. (2016). Role of nutrients and illuminance in predicting the fate of fungal mediated petroleum hydrocarbon degradation and biomass production. Journal of Environmental Management. 176: 54-60.

[21] Guarino, C., Spada, V. and Sciarrillo, R. (2017). Assessment of three approaches of bioremediation (natural attenuation, landfarming and bioaugmentation - assisted landfarming) for a petroleum hydrocarbons contaminated soil. Chemosphere. 170: $10-16$.

[22] Sayler, G. S., Hooper, S. W., Layton, A. C. and King, G. M. H. (1990). Catabolic plasmids of environmental and ecological significance. Microbial Ecology. 19: 1-20.

[23] Whyte, L. G., Bourbonnie're, L. and Greer, C. W. (1997). Biodegradation of petroleum hydrocarbons by psychrotrophic Pseudomonas strains possessing both alkane (alk) and naphthalene (nah) catabolic pathways. Applied Environmental Microbiology. 63: 3719-3723.

[24] Colwell, R. R., Walker, J. D. and Cooney, J. J. (1977). Ecological aspects of microbial degradation of petroleum in the marine environment. Critical Reviews in Microbiology. 5: 423-445.

[25] Atlas, R. M. (1992). Petroleum microbiology. In: Encyclopedia of Microbiology, Academic Press, Baltimore, Md, USA, 363369.

[26] Amund, O. O. and Nwokoye, N. (1993). Hydrocarbon potentials of yeast isolates from a polluted Lagoon. Journal of Scientific Research and Development. 1: 65-68.

[27] Lal, B. and Khanna, S. (1996). Degradation of crude oil by Acinetobacter calcoaceticus and Alcaligenes odorans. Journal of Applied Bacteriology. 81: 355-362.

[28] Jones, D. M., Douglas, A. G., Parkes, R. J., Taylor, J., Giger, W and Schaffner, C. (1983). The recognition of biodegraded petroleum-derived aromatic hydrocarbons in recent marine sediments. Marine Pollution Bulletin. 14: 103-108.

[29] Habe, H., Omori, T. (2003). Genetics of polycyclic aromatic hydrocarbon metabolism in diverse aerobic bacteria. Bioscience, Biotechnology and Biochemistry. 67: 225-243.

[30] Yakimov, M. M., Timmis, K. N., Golyshin, P. N. (2007). Obligate oil-degrading marine bacteria. Current Opinion in Biotechnology. 18: 257-266.

[31] Brooijmans, R. J. W., Pastink, M. I., Siezen, R. J. (2009). Hydrocarbon-degrading bacteria: the oil-spill clean-up crew. Microbial Biotechnology. 2: 587-594.

[32] Rahman, K. S. M., Rahman, K. J., Kourkoutas, Y., Petsas, L., Marchant, R. and Banat, I. M. (2003). Enhanced bioremediation of $n$-alkane in petroleum sludge using bacterial consortium amended with rhamnolipid and micronutrients. Bioresource Technology. 90: 159-168.

[33] Floodgate G. (1984). The fate of petroleum in marine ecosystems. In Petroleum Microbiology, R. M. Atlas, Macmillan New York, NY, USA. 355-398.
[34] Chaillan, F., Le Fleche, A., Bury, E., Phatavong, Y. H., Grimont, P., Saliot, A. and Oudot, J. (2004). Identification and biodegradation potential of tropical aerobic hydrocarbon degrading microorganisms. Research in Microbiology. 155: 587-595.

[35] Daugulis, A. J. and McCracken, C. M. (2003). Microbial degradation of high and low molecular weight polyaromatic hydrocarbons in a two-phase partitioning bioreactor by two strains of Sphingomonas sp. Biotechnology Letters. 25: 14411444.

[36] Pinedo-Rivilla, C., Aleu, J. and Collado, I. (2009). Pollutants biodegradation by fungi. Current Organic Chemistry. 13: 1194 1214.

[37] Cerniglia, C. and Sutherland, J. (2010). Degradation of polycyclic aromatic hydrocarbons by fungi. In: McGenity, T. J., van der Meer, J. R. and de Lorenzo, V. (Eds) Handbook of hydrocarbon and lipid microbiology. Springer, Berlin/Heidelberg. 2079-2110.

[38] Saraswathy, A. and Hallberg, R. (2002). Degradation of pyrene by indigenous fungi from a former gas-works site. FEMS Microbiology Letters. 210: 227-232.

[39] Gesinde, A. F., Agbo, E. B., Agho, M. O. and Dike, E. F. C. (2008). Bioremediation of some Nigerian and Arabian crude oils by fungal isolates. International Journal of Pure and Applied Science. 2: 37-44.

[40] Cooney, J. J., Edmonds, P. and Brenner, Q. M. (1986). Growth and survival of fuel isolates in hydrocarbon fuel emulsions. Applied Microbiology. 16: 569-571.

[41] Bailey, N. J. L., Jobson, A. M. and Rogers, M. A. (1973). Bacterial degradation of crude oil: comparison of field and experimental data. Chemical Geology. 11: 203-221.

[42] Hill, E. C. and Thomas, A. R. (1976) Microbiological aspects of supersonic aircraft fuel. In: Sharpley, J. M. and Kaplan, A. M. (Eds) Proceedings of the third international biodegradation symposium. Applied Science Publishers Ltd., London, 157174.

[43] Hill, E. C. (1978). Biodegradation of hydrocarbon-based products in industrial use. In: Watkinson, J. R. (Ed) Developments in biodegradation of hydrocarbons-1. Applied Science Publishers, London, 201-226.

[44] Davies, J. S. and Westlake, D. W. S. (1979). Crude oil utilization by fungi. Canadian Journal of Microbiology. 25: 146-156.

[45] Bogusławska-Was, E. and Da Browski, W. (2001). The seasonal variability of yeasts and yeast-like organisms in water and bottom sediment of the Szczecin Lagoon. International Journal of Hygiene and Environmental Health. 203: 451-458.

[46] O'Brien, P. Y. and Dixon, P. S. (1976). The effects of oil and oil components on algae; a review. British Phycological Journal. 11: 115-142.

[47] Bossert, I. and Bartha, R. (1984). The fate of petroleum in soil ecosystems. In: Atlas RM (Ed) Petroleum microbiology. MacMillan, New York. 434-476.

[48] Bartha, R. and Bossert, I. (1984). The treatment and disposal of petroleum wastes. In: Petroleum Microbiology, R. M. Atlas, Macmillan, New York, NY, USA. 553-578. 
[49] Cooney, J. J. (1984). The fate of petroleum pollutants in fresh water ecosystems. In: Petroleum Microbiology, R. M. Atlas, Macmillan, New York, NY, USA. 399-434.

[50] Bagi, A., Pampanin, D. M., Brakstad, O. G. and Kommedal, R. (2013). Estimation of hydrocarbon bio-degradation rates in marine environments: a critical review of the Q10 approach. Marine Environmental Research. 89: 83-90.

[51] van Beilen, J. B., Funhoff, E. G., van Loon, A., Just, A., Kaysser, L., Bouza, M., Holtackers, R., Rothlisberger, M., Li, Z. and Witholt, B. (2006). Cytochrome P450 alkane hydroxylases of the CYP15 family are common in alkane-degrading eubacteria lacking integral membrane alkane hydroxylases. Applied Environmental Microbiology. 72: 59-65.

[52] van Beilen, J. B., Funhoff, E. G. (2007). Alkane hydroxylases involved in microbial alkane degradation. Applied Environmental Microbiology. 74: 13-21.

[53] Yeung, C. W., van Stempvoort, D. R., Spoelstra, J., Bickerton, G., Voralek, J. and Greer, CW. (2013). Bacterial community evidence for anaerobic degradation of petroleum hydrocarbons in cold climate groundwater. Cold Regions Science and Technology. 86: 55-68.

[54] Boyd, S. A. and Shelton, D. R. (1984). Anaerobic biodegradation of chlorophenols in fresh and acclimated sludge. Applied Environmental Microbiology. 47: 272-277.

[55] Chen, M., Hong, C. S., Bush, B. and Rhee, G. Y. (1988). Anaerobic biodegradation of polychlorinated biphenyls by bacteria from Hudson River sediments. Ecotoxicology and Environmental Safety. 16: 95-105.

[56] Azadpour-Keeley, A., Keeley, J. W., Russell, H. H. and Sewell, G. W. (2001). Monitored natural attenuation of contaminants in the subsurface: processes. Ground Water Monitoring and Remediation. 21: 97-107.

[57] Zhou, E. and Crawford, R. L. (1995). Effects of oxygen, nitrogen, and temperature on gasoline biodegradation in soil. Biodegradation. 6: 127-140.

[58] Salminen, J. M., Hanninen, P. J., Leveinen, J., Lintinen, P. T. J. and Jorgensen, K. S. (2006). Occurrence and rates of terminal electron-accepting processes and recharge processes in petroleum hydrocarbon-contaminated subsurface. Journal of Environmental Quality. 35: 2273-2282.

[59] Hasinger, M., Scherr, K. E., Lundaa, T., Brauer, L., Zach, C. and Loibner, AP. (2012). Changes in iso- and n-alkane distribution during biodegradation of crude oil under nitrate and sulphate reducing conditions. Journal of Biotechnology. 157: 490-498.

[60] McDonald, I. R., Miguez, C. B., Rogge, G., Bourque, D., Wendlandt, K. D., Groleau, D. and Murrell, J. C. (2006). Diversity of soluble methane monooxygenase-containing methanotrophs isolated from polluted environments. FEMS Microbiology Letters. 255: 225-232.

[61] van Beilen, J. B., Neuenschwunder, M., Smits T. H. M., Roth, C., Balada, S. B. and Witholt, B. (2003). Rubredoxins involved in alkane degradation. Journal of Bacteriology. 184; 1722-1732.

[62] Iida, T., Sumita, T., Ohta, A. and Takagi, M. (2000). The cytochrome P450ALK multigene family of an n-alkane-assimilating yeast, Yarrowia lipolytica: cloning and characterization of genes coding for new CYP52 family members. Yeast. 16: 1077-1087.
[63] van Beilen, J. B., Funhoff, E. G., Van Loon, A. (2006). Cytochrome P450 alkane hydroxylases of the CYP153 family are common in alkane-degrading eubacteria lacking integral membrane alkane hydroxylases. Applied and Environmental Microbiology. 72: 59-65.

[64] Maeng, J. H. O., Sakai, Y., Tani, Y. and Kato, N. (1996). Isolation and characterization of a novel oxygenase that catalyzes the first step of n-alkane oxidation in Acinetobacter sp. strain M-1. Journal of Bacteriology. 178: 3695-3700.

[65] Adebusoye, S. A., Ilori, M. O., Amund. O. O., Teniola, O. D. and Olatope, S. O. (2007). Microbial degradation of petroleum hydrocarbons in a polluted tropical stream. World Journal of Microbiology and Biotechnology. 23: 1149-1159.

[66] Abu, G. O. and Ogiji, P. A. (1995). Initial test of a bioremediation scheme for the clean-up of an oil-polluted water body in a rural community in Nigeria. Bioresource Technology. 58: 7-12.

[67] Radwan, S. S., Al-Hassan, R. H. and Salamah, S. (2002). Bioremediation of oily sea water by bacteria immobilized in biofilms coating microalgae. International Biodeterioration and Biodegradation. 50: 55-59.

[68] Cerniglia, C. E., Gibson, D. T., van Baalen, C. (1983). Oxidation of naphthalene by cyanobacteria and microalgae. Journal of General Microbiology. 116: 495-500.

[69] Bossert, I. and Bartha, R. (1984). The fate of petroleum in soil ecosystems. Macmillan Publishing Co., New York. 3: 434-476.

[70] Xua, Y. and Lu, M. (2010). Bioremediation of crude oil-contaminated soil: Comparison of different biostimulation and bioaugmentation treatments. Journal of Hazardous Materials. 83: 395-401.

[71] van Hamme, J. D., Singh, A. and Ward, O. P. (2003). Recent advances in petroleum micro-biology. Microbiology and Molecular Biology Reviews. 67: 503-549.

[72] Atlas, R. M. (1988). Microbiology-fundamentals and applications, $2^{\text {nd }}$ edn. Macmillan, New York.

[73] Widdel, F. and Rabus, R. (2001). Anaerobic biodegradation of saturated and aromatic hydro-carbons. Current Opinion in Biotechnology. 12: 259-276.

[74] Diaz, M. P., Boyd, K. G. and Grigson, S. J. W. (2002). Biodegradation of crude oil across a wide range of salinities by an extremely halotolerant bacterial consortium MPD-M, immobilized onto polypropylene fibers. Biotechnology and Bioengineering. 79: 145-153.

[75] Schwarz, J. R., Walker, J. D. and Colwell, R. R. (1974). Deep-sea bacteria: Growth and utilization of hydrocarbons at ambient and in situ pressure. Applied Microbiology. 28: 982-986.

[76] Schnoor, J., Licht, L. A., McCutcheon, S. C., Wolfe, N. L. Carreira, L. H. (1995). Phytoremediation of organic and nutrient contaminants. Environmental Science and Technology. 29: 318A-323A.

[77] Miya, R. K. and Firestone, M. K. (2001). Enhanced phenanthrene biodegradation in soil by slender oat root exudates and root debris. Journal of Environmental Quality. 30: $1911-1918$ 